Organizatsiya i metodika informatsionnoy raboty. - 2009. - № 12. - S. 15-22.

Стаття надійшла до редакції 15.03.2020

\title{
N. Gaiduk
}

FUNCTIONS AND NATURE OF INFORMATION AND LIBRARY ACTIVITY IN THE SYSTEM OF SCIENTIFIC COMMUNICATION

The article observes the quantitative and qualitative structure of the document flow of scientific periodicals in Documentary Science on materials of publications in the professional scientific journal "Library Science. Documentary Science. Information Science» for the period of 2017 - 2019, using the bibliometric analysis to demonstrate the possibilities of this method as a way of studying the dynamic development of certain documentary flows. Considering the large amount of information, that is transmitted and consumed, to organize it, it is necessary to study certain document flows in dynamics. It is believed that the most appropriate method for such research is the method of bibliometric analysis, which allows, based on the analysis of quantitative indicators of document flows of a particular industry, to determine the inherent patterns and to modulate it. The main subject of study in bibliometric research is usually various publications of certain documentary flows, which are often grouped according to different characteristics, for example, to authors, journals, thematic columns, countries, etc.

The author studies the total quantitative component of publications in Documentary Science and a part of each segment in the total number of publications; language structure of the document flow; one of the criteria for analyzing the document flow of scientific periodicals in Documentary Science is a part of individual publications by years and coauthored. In addition, the parameter of the bibliometric analysis is the analysis of the documentary flow of scientific periodicals in Documentary Science according to the author's feature. Ukrainian-language publications predominate in the documentary flow of scientific periodicals on documentary studies.

Regarding the analysis of the documentary flow of scientific periodicals on document science on the basis of authorship, in the three analyzed years we find about 30 authors who have been published in the journal, six of which have more than one publication.

Using bibliometric analysis, we investigated the quantitative and qualitative structure of the document flow of scientific periodicals in document science in a professional scientific journal and identified features of the quantitative dynamics of publications for the period, linguistic and authorial components, thus demonstrating the possibilities of this method as a way to study the dynamic development of certain document flows. one of the effective means of information management of scientific activity.

Key words: Archival Science, bibliometric analysis, bibliometric, Library \& Information Science, document flow, Documentary Science, quantitative analysis.

УДК 008(=161.2):070

\author{
К. В. Кислюк
}

ОСОБЛИВОСТІ РЕПРЕЗЕНТАЦИЙ УКРАЇНСЬКОЇ ІДЕНТИЧНОСТІ У ВІЗУАЛЬНОМУ КОНТЕНТІ ПОПУЛЯРНИХ ТЕЛЕГРАМ-КАНАЛІВ 
У статті розглянуто особливості репрезентацій української ідентичності у візуальному контенті 5 найпопулярніших Телеграм-каналів ( Украина 24/7», «Украина сейчас», "Украина Online», «ТСН», «Инсайдер UА»). Було виокремлено дві групи ї̈ маркерів - Political Identity (сполучення синьо-жовтих кольорів, прапор чи тризуб як центр зображення або домінуючий фон) та Military (чоловіки та жінки в украӥнській військовій формі, зброя та військова техніка). Їх питому вагу слід рахувати значно вищою, ніж формальні по 2-3\% від загального візуального масиву. Провідною визначено першу групу, яка уособлюе громадянсько-політичну ідентичність. Ï̈ поширення пояснено спрямуванням внутрішньої політики чинної влади на «громадян України», не недиференційованих за геополітичними і ияіннісними уподобаннями.

Зазначено на основі попередніх досліджень автора, щзо в сочіальних мережах Фейсбук та Інстаграм знано ширше представлений інший, етнонаснажений рівень української ідентичності. Фактично єдиним спільним сучасним символом України, одночасно візуальним і меморіальним, у різних медійних каналах виявилися поодинокі зображення Монументу Незалежності на однойменному майдані в Києві. Це чітко демонструє незавершеність процесів постмодернізації Украӥни на рівні цінностей, культурної пам'яті та ієрархії ідентичностей.

Ключові слова: ідентичність, культура, медіа, Телеграм, українська ідентичність, украӥнська культура.

DOI 10.34079/2226-2830-2020-10-19-37-48

У даній публікації автор продовжує дослідження в соціокультурних вимірах української ідентичності, розпочате ним у статтях 2015-2019 рр. і проміжно підсумоване в монографії «Українська культура 1 чверті XXI ст.: повороти модернізаційних перетворень» (Київ, 2018).

Перетворення ідентифікаційної тематики на своєрідну концептуальну ікону (iconic concept) - актуальний світовий науковий тренд, спричинений занепадом усталених для I половини XX ст. національно-державних - маркерів ідентичності під впливом глобалізаційних процесів, «конфлікту цивілізацій» (С. Гантінгтон) та настання «інформаційної епохи» 3 мережовою, горизонтальною побудовою усіх без винятку соціально-комунікативних зв'язків (М. Кастельс). 2018 року в каталогах Бібліотеки Конгресу США налічувалося понад 1000 англомовних видань зі словом «ідентичність» у назві, проти 37 у 1950-і pp. [9, p. 2].

В Україні рефлексії над власною ідентичністю, які відбувались від 2000-х рр. під впливом невпинного «прощання з імперією» (О. Гнатюк), значно розширилися в добу системної кризи II Української республіки (2013-2019рр.). Щойно завдяки спеціалізованим дослідженням зазначена проблема постала у всій своїй історикокультурній глибині та суспільно-політичній ширині, зміна влади в країні поставила ці дослідження на своєрідну паузу.

До представників відповідної історіографічної традиції можуть бути зараховані і сучасні західні дослідники (Е. Вільсон, С. Счкельчик), і митці української діаспори останніх поколінь (С. Грабовський, 3. Когут, М. Павлишин, С. Плохій, О. Пріцак, О. Субтельний, О. Толочко, І. Шевченко, Р. Шпорлюк), і вітчизняні літератори та публіцисти (Ю. Андрухович, С. Дацюк, С. Жадан, О. Забужко, Р. Кісь та ін.), власне фахові науковці. Серед останніх ми виділяємо праці Л. Нагорної, М. Степико, особливо М. Рябчука [7]. Актуальний і дотепер маловивчений погляд на українську ідентичність пропонує Ю. Половинчак. На жаль, авторка зосереджує свою увагу не на змісті, а на особливостях, перебігу, механізмах, інституціях трансформації української 
ідентичності в сучасному інформаційно-комунікаційному середовищі. Підкреслюючи, наприклад, у цікавому нам аспекті надзвичайно «компресивність» медійних образів, їх «здатність у доступному виді передавати значні масиви інформації» [4, с. 132]. У західній гуманітаристиці останніми роками поширюється інший підхід. Ідентичність розглядається як політико-моральний елемент, важливіший, навіть, за соціальнополітичні інституції. Його зрілість доводить довершеність західної ліберальної демократії [11]. Порівняно 3 цим українська етнополітична ідентичність виглядає як попередній етап розвитку. Попри беззаперечні наукові здобутки, особливо в царині вивчення історико-культурних витоків української ідентичності, усім зазначеним працям бракує культурологічності підходу, розгляду питання в широкому соціокультурному контексті, визначення його культурницьких детермінацій.

Метою статті $є$ удосконалення авторської концепції багаторівневої української ідентичності. Згідно до неї, формальна громадянсько-політична ідентичність притаманна 70\% громадян України; фактична, мовно-культурна - 50\% мешканцям України а реальна, етнонаснажена, властива 25\% українців. На думку авторка, структура української ідентичності відображає не стільки спізнілість процесів націо- та державотворення, згідно до класичних концепцій речників діаспори («хвороба бездержавності» В. Липинського), скільки багатошаровість української культури, що $є$ наслідком дуже своєрідної траєкторії процесів навздогінної модернізації.

В основу методології дослідження покладене поєднання кількісних (статистичний метод) та якісних (інтерпретативний метод, порівняльний метод, семантичний метод) дослідницьких інструментів, найближчим аналогом якого $\epsilon$ контент-аналіз, у загальнотеоретичному контексті «візуальної культурології». На відміну від інших дисциплін і програм дослідження візуального, остання має не стільки заглиблюватися у специфіку візуальних конструкцій як таких, скільки визначати взаємозв'язок між візуальністю та культурою - віддзеркалення у візуальних образах соціокультурних трендів та ідентифікацію процесів зворотного впливу візуального на культуру.

На першому етапі роботи автором було проаналізовано увесь візуальний зміст найпопулярніших Телеграм-каналів, відібрано найбільш характерніші, на його думку, ідентифікаційні маркери, обраховано їх питому вагу. На другому етапі роботи найбільш показові візуальні маркери сучасної української ідентичності було проінтерпретовано методом соціокультурної детермінації та соціокультурної каузальності на предмет виявлення їх причинно-наслідкового зв'язку із соціокультурним контекстом. На третьому етапі роботи проведене дослідження було розширено семантичним аналізом альтернативних візуальних образів української ідентичності, а також порівнянням поточних результатів 3 даними соціологічних досліджень (Центру Разумкова, Київського міжнародного інституту соціології (КМІС), Соціологічної групи «Рейтинг») та відомостями, отриманими автором раніше під час дослідження характерних візуальних репрезентантів української культури в мережах Інстаграм і Фейсбук.

Зазвичай, Telegram узагалі не враховується серед найпопулярніших світових та українських соціальних мереж [9], адже формально - це мессенджер. Проте, за даними маркетингових досліджень групи Kantar Ukraine, у березні 2020 року Телеграм входив у ТОП-10 найбільш популярних мобільних додатків [5] і займав 28 місце серед найвідвідуваніших сайтів. При виборі предмету дослідження було також взято до уваги критерій впливовості, здатність одночасно продукувати новини і формувати медійний порядок денний (newsmaker) та відігравати роль впливового суб'єкта (actor) важливих соціальних подій.

Хоча медійна специфіка каналу комунікації позначається на його змісті 
переважною мірою (це зазначав ще автор першої культурологічної теорії медіа М. Маклуен з його «засіб сам по собі є повідомленням»), однак не виключає можливості презентувати прямо або опосередковано особистість автора повідомлення, його соціально-гендерну позицію чи культурну ідентифікацію.

Так, один із популярних вітчизняних Телеграм-каналів - «Музика SAMBURSKA» (https://tttt.me/music_samburska), який належить молодій дівчині з Івана-Франківська Тані Самбурській. Остання професійно заробляє на соціальних мережах (адже, лише один іiі інстаграмний профіль (_samburska) має 1,3 млн. передплатників. На перший погляд, у їі Телеграм-каналі (390 фото) та профілі в Інстаграм (228 публікацій) відсутні зображення ідентифікуючого змісту (знайдено лише одно фото у вишиванці). Але, на відміну від інших топових каналів у Телеграм, Таня використовує виключно українську мову, яка, на нашу думку, є однією з провідних ознак середнього, фактичного, рівня української ідентичності.

Нами було досліджено візуальний контент 5 найпопулярніших українських Телеграм-каналів згідно до автентичної статистики (https:/uk.tgstat.com), за винятком каналу, присвячений коронавірусу. Це (назви подаються мовою оригіналу) - «Украина 24/7», «Украина сейчас», «Украина Online», «ТСН» (телеграмна служба новин), «Инсайдер UA», які належать до категорії «Новини та ЗМІ». На момент завершення дослідження на початку червня 2020 року кількість підписників кожного 3 цих каналів фіксувалась у діапазоні 250-500 тис., а охоплення аудиторії перебувало в діапазоні від 220 тис. до 1,6 мільйона (але мало тенденцію до різкого зниження).

Генеральна вибіркова сукупність досліджуваних візуальних образів у цих каналах склала 11300 одиниць. Абсолютна більшість 3 них представляли собою т. зв. «ілюстративні фотографії». Ми вважаємо, що репродукуючи скорочену версію новин, журналісти та редактори використовують, навіть підсвідомо, у супровідних зображеннях найбільш усталені чи стереотипізовані образи, серед яких крупним планом трапляються саме маркери ідентичності. Група фото, присвячених одній події, зараховувалась як одна ілюстрація. Однакові ілюстративні фотографії на різних Телеграм-каналах обраховувалися для кожного каналу окремо.

Загалом, нами виділено дві великі групи образів, які репрезентують вітчизняну ідентичність зразка 2020 року. Першу групу ми умовно позначили як Political Identity, другу - як Military. Провідним маркером першої групи, яка відображає достатньо поширений у сучасному світі громадянсько-політичний рівень ідентичності, виявилась національна жовто-синя кольорова гама, зображення українського прапора та малого герба України - тризуба, банкнот. До групи Political Identity були зараховані образи, де сполучення синє-жовтих кольорів, прапор і герб є як центром зображення, так і певним фоном (поряд із діячами, заходами, зібраннями, фарбуванням споруд і транспорту, зображеннями на плакаті чи інфографіці тощо), який уможливлював однозначну ідентифікацію зображеного з Україною.

Кількість унікальних ідентифікаційних образів для топ-5 українських Телеграмканалів була зафіксована в межах 40-70 зображень для групи Political Identity та від 20 до 50 зображень для групи Military. Це склало по 2-3\% від загального візуального масиву. Сумарна питома вага обох груп візуальних маркерів української ідентичності вийшла за межі статистичної похибки і доводить їх певну значущість. Через велику сенсонавантаженість цих візуальних маркерів їх фактичну вагу слід рахувати ще вищою.

Позаяк усі розглядувані канали почали активно працювати навесні-влітку 2019 року, ми не виявили статистично значущих кореляцій у розміщені образів політичної ідентичності у зв’язку із переходом від президентської каденції Петра Порошенка до 
президентської каденції Володимира Зеленського. Це доводить сталість відповідного ідентифікаційного тренду.

Додатковим елементом громадянсько-політичної ідентичності українців у Телеграмі можна визнати іiі західну зорієнтованість. Постійно зустрічаються зображення іноземних політиків, міст, установ. Кількісно вони не переважають маркери української ідентичності, однак у просторово обмеженому (екраном смартфона) інформаційному каналі утворюють наочний асоціативний зв'язок з ними (навіть якщо ілюструється повідомлення, з Україною безпосередньо не пов'язане). Гадаємо, ця особливість вповні відображає симпатії суспільства. Якщо до НАТО продовжує зберігається упереджене ставлення майже половини населення, то на уявному референдумі за вступ України до СС проголосувало би взимку 2020 року дві третини $(63,3 \%)$ усіх опитаних Центром Разумкова [6] і більше половини $(51,6 \%)$ опитаних Київським міжнародним інститутом соціології (КМІC) українців [2]. Серед аудиторії Телеграм, яка здебільшого мешкає у великих українських містах (+50 тис. населення) і є соціально активною, відсоток прозахідних симпатиків вочевидь $є$ значно вищим.

Домінування політичної ідентичності в Телеграм-каналах має кілька пояснень. Це i специфіка самих топових Телеграм-каналів як каналів новин, і загальносвітові тенденції, і вище місце в ієрархії ідентичності українців. У сучасній суспільнополітичній кон'юнктурі України воно, на нашу думку, вповні відображає тренд до збільшення відсотку тих, хто ідентифікує себе в першу чергу громадянином України. За даними Соціологічної групи «Рейтинг», у 2010 році тих, хто міг себе так назвати було $57 \%$, а у 2019 році - 65\%. Цьогоріч було зафіксовано найменшу за час досліджень кількість тих, хто ідентифікував себе як жителя свого регіону, міста, села (15\%), також зменшилась кількості тих, хто обрав би альтернативу «просто людина» (18\% цьогоріч, $29 \%$ - минулого року) [3]. Саме на такого, не недиференційованого за геополітичними і ціннісними уподобаннями, виборця розрахована політика нинішнього президента. Разом із тим, занизька питома вага розглядуваної проблематики відображає фактичне призупинення політики «лагідної українізації», яку влада чинна, не відміняючи формально, фактично відсуває на задній план суспільного «порядку денного».

До групи Military ми включили зображення чоловіків і жінок в однострої, у шоломах і бронежилети або без, із зброєю або без, фото військової техніки з людьми або без, фото військових у польових умовах, у місцях постійної дислокації, парадах, повсякденному житті, які представляли ЗСУ, НГ, СБУ, Державну прикордонну службу. Прикметне, що, за винятком полку «Азов» і створеної на його основі політичної партії «Національний корпус», не зустрічається зображень представників добровольчих і парамілітарних формувань, популярних у 2014-2915 рр. Цей факт, на нашу думку, відображає процес інституціоналізації подібних утворень, цілком закономірний не тільки 3 військової точки зору, але із точки зору знівелювання гібридних ідеологічних загроз.

Із переходом до президентської каденції Володимира Зеленського зі змісту образів групи Military (щоправда це стосується, радше, інформаційного простору в цілому) фактично щезли теми знищення ворожої техніки, особового складу, зайняття нових позицій. Спроба надати мирному врегулюванню «конфлікту на Сході України» нового поштовху призвела до вилучення теми військової активності ЗСУ на Донбасі, хоча розвороту тренду не відбулося.

Закріплення мілітарних маркерів української самтотожності якнайкраще ілюструє факт перебування України у стані неоголошеної війни. Це - попри дотепер поширене у буденній свідомості уявлення «Ніякої війни немає» (автор особисто чув його, навіть, 
від співробітника одного із військкоматів м. Харкова), а також попри констатоване експертами Інституту масової інформації стале зниження частоти згадувань про Операцію об'єднаних сил в інформаційному полі України в останні 2-3 роки [2].

У реальності будь-яка подія - чи то загострення на фронті, чи то мирне розведення сил і засобів на певних ділянках фронту, чи то загибель українських захисників, чи то знищення ворожої техніки та особового складу, закупівля техніки та озброєнь за кордоном чи поставки техніки, корупція в «Укроборонпромі», реформування призову чи системи харчування, призначення чи переміщення військових керівників, обмін військовими і цивільними полоненими, затримання ворожих агентів, призов на строкову службу, останнім часом - стан захворюваності на COVID-19 серед особового складу ЗСУ продовжують залишатись важливими новинами.

Позаяк маємо по кволу мілітаризацію суспільної свідомості (навіть, помірковані темпи якої після завершення активної фази бойових дій на Донбасі дозволяють вести боротьбу на виснаження максимально тривалий час), йдеться, радше, про ситуативний і вкрай мінливий стан. За нашою стратифікацією, готовість до оборони держави $\epsilon$ показником зовсім іншого рівня ідентичності - реального, етнонаснаженого. Його питома вага в ідентифікаційній ієрархії українців є найнижчою. Наприклад, лише $23 \%$ опитаних Соціологічної групою «Рейтинг» восени 2019 року виступили за продовження військових дій до повного відновлення української влади на всьому Донбасі [8].

Тому трансляція образів групи Military виглядає відірваною від трансляції української ідентичності. Це стає особливо помітним завдяки слабкому семантичному зв'язку з іншими маркерами українськості. Якщо на офіційних Фейсбук-сторінках армійських

бригад (https://www.facebook.com/pg/93OMBr/photos; https://www.facebook.com/pg/72brigade.bes $\mathrm{t} /$ photos/?ref=page_internal) частина мілітарних зображень $\epsilon$ прямо сполученою 3 етнонаціональною символікою (рис. 1.), то у Телеграм-каналах домінує, так би мовити, чисте Military, ідентифікаційні характеристики якого (форма, шеврони, нашивки, нагороди, знаки на військовій техниці) не винесено на передній план.

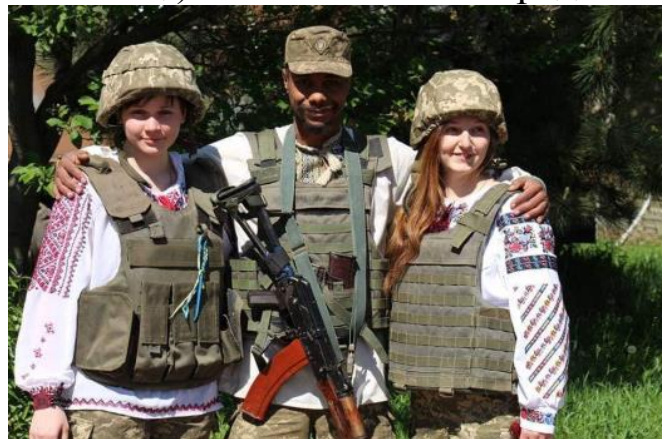

Рисунок 1 - Military з етнонаціональним акцентом

Здобуті нами результати помітно контрастують із відомостями нашого аналізу візуальних репрезентацій української культури в соціальних мережах Інстаграм (спільнота ukraine_insta, «Все про Україну та українців», «Батьківщина очима українців») та Фейсбук («Українці всього світу - єднаймося!»), вперше проаналізованих наприкінці 2018 року і повторно студійованих у середині 2020 року.

У цих мережах виявилося значно важче простежити громадянсько-політичну версію національної специфіки України. Зображення із синьо-жовтою колірною символікою, прапор і гербом України, якщо і траплялися, то були часто закцентовані не 
на змісті зображуваного, а на його ексклюзивності чи візуальній привабливості (тракторний причіп з пофарбованим у жовто-синє кузовом, прапор у пейзажі над прірвою тощо). Натомість переважали зображення, які можна віднести до етнокультурної версії української ідентичності, зазвичай, фемінізовані i рустикалізовані образи України (жінка в національному вбранні, етнокультурна символіка, лани зі стиглою пшеницею або соняшником). У Телеграм-каналах подибуємо лише поодинокі подібні зображення, які не складають статистично значущих показників. Це можуть бути портрети окремих політиків у вишиванках (С. Вакарчук), ілюстративні фото до певних подій (Свято вишиванки, зміни у шкільній програмі). Пейзажні та ландшафтні зображення України тут повністю позбавлені не тільки ідентифікаційних орієнтирів, але й культурної самоцінності. Гірські пейзажі ілюструють законодавчу заборону вирубки лісів у Карпатах; фото ланів із соняшником і пшеницею супроводжуються питаннями про економічну доцільність відкриття ринку землі; а сільські обрії Дніпропетровщини виявляються заповненими заздалегідь виритими могилами для жертв пандемії тощо.

У відфотошопленому світі Інстаграма війні, зрозуміло, зовсім не знайшлося місця. У версіï ukraine_insta 2020 року із 1344 публікацій ми знайшли лише два мілітарні образи. Мілітарна проблематика у Фейсбуці з причини суспільно-політичного спрямування цієї соцмережі виявилась більш наочною. У спільноті «Українці всього світу - єднаймося!» із 2158 публікацій ми виявили нині 308 мілітарних зображень, або понад 14\% від усього візуального масиву. Це на перший погляд підтверджує зв'язок із реальним рівнем української ідентичності. Серед останніх 68 образів, або 22\% відсотки, можна визначити як «жіночі мілітарі». Це в цілому корелює 3 трендом до збільшення кількості жінок на військовій службі. Однак, ця кількість (складає трохи більше 3\% від загального візуального масиву) виглядає у рази меншою порівняно із сотнями зображень етнокультурного образу України-жінки, що, радше, візуалізує протилежний наратив - слабкої, миролюбної країни, яка не хоче війни.

Фактично ми стикаємось із явищем соціального інфантилізму, викликаного незавершеністю та різновекторністю процесів навздогінної модернізації. Це стосується i першої хвилі такої модернізації, коли розтягнутий до середині XX ст. перехід українських земель до рівня індустріально-аграрного суспільства значною мірою впливав на збереження архаїчних патернів у суспільній свідомості, власне, відзначених у класичних теоріях українського національного характеру (Д. Чижевський); і другої хвилі, коли перехід до постіндустріального суспільства, що вимагає різкого збільшення індивідуальної соціальної активності та відповідальності, викликає «захисну реакцію» більшості «пересічних українців».

Спільний момент у візуальних репрезентаціях української культури та української ідентичності в Telegram, Facebook, Instagram ми вбачаємо у відсутності чітко сформованого сучасного символічного ряду. Єдиним символом, одночасно меморіальним і візуальним, який зустрічається (щоправда, в одиничних випадках) в кожному із розглянутих комунікативних каналів, є Монумент Незалежності в Києві. У випадку з Україною гомогенізація іiі меморіального простору (передусім, через політику декомунізації) допоки значно випереджає його розширення новітніми складовими. Хоча у ранніх культурах відповідний процес розтягувався та 3-4 покоління (Я. Ассман), у сучасних успішних у плані політико-економічної модернізації суспільствах меморіальна традиція створюється і усталюється значно швидше, оскільки асоціюється у більшості громадян з разючими перемінами на краще за їх життя. I саме вона стає підмурівком для громадянсько-політичної ідентичності, слабкість якого робить цю ідентичність менш виразною. 
Уважаємо, що між різними рівнями української ідентичності, презентованими через різні медійні канали, так само які між різними групами ідентифікаційних маркерів, немає нездоланної прірви. Питання, радше, полягає у використанні певної моделі взаємовідносин між ними. У досліджених нами Телеграм-каналах ми виокремили три можливі моделі (щоправда, різного ступеню опрацьованості).

Першу модель демонструють нам зображення в популярному каналі політика $\mathrm{i}$ блогера Анатолія Шарія (@ASupersharij). Попри звинувачення в антиукраїнських поглядах, знаходимо і там ідентифікаційні зображення груп Political Identity та Military. У каналі «Анатолій Шарій» Political Identity та Military часто поєднуються (рис. 2.), вочевидь, демонструючи наратив близкості України до колись поширених у країнах, що розвиваються, режимів «військової хунти» або фашистських практик доби Другої Світової війни (популярний меседж доби «русской весны» весни-осені 2014 року).

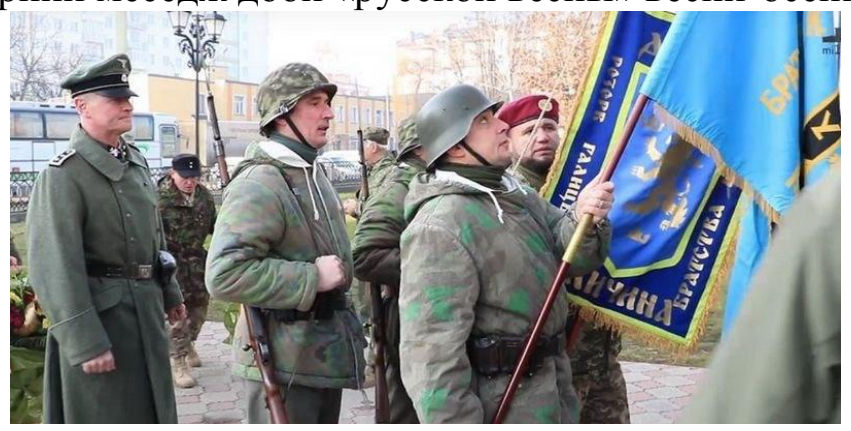

Рисунок 2 - Образ України як націонал-фашистської держави.

Прямо протилежну модель - «ультрапатріотичну - демонструє зображення плакату, присвяченого Дню захисника Вітчизни, який ми знайшли на каналі «Инсайдер UA». Там намальовано вояка в сучасному однострої поряд із козаком на фоні лану стиглої пшениці (рис. 3.). Безліч однотипних йому було створено після офіційного встановлення свята. Художня умовність, а не документальність розглядуваного візуального образу (вона прочитується уже в тому факті, що військовослужбовця ЗСУ вдягнуто не в офіційну польову уніформу, а в т. зв. «бундес», камуфляж, який асоціюється з армією ФРН) постає засобом конструювання бажаного семантичного зв'язку між різними рівнями української ідентичності, між різними шарами української культури.

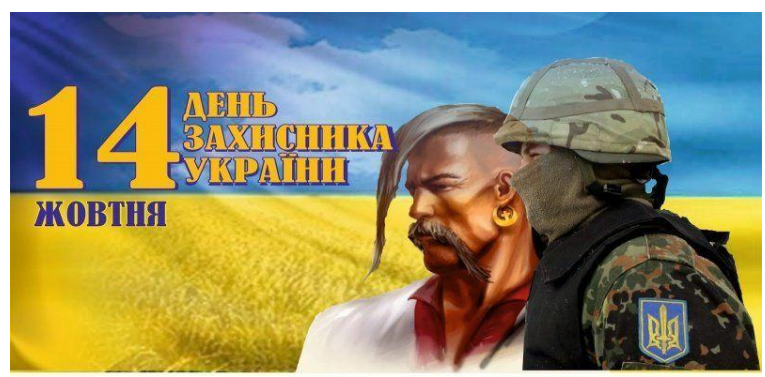

Рисунок 3 - Ультрапатріотичний образ України як могутньої козацької держави.

Сучасна ідентичність, попри назовні домінуючу ієрархічну позицію на зображені (попереду та праворуч від глядача), зрештою виглядає відсунутою етнічною ідентичністю (представленою козаком) через однозначно домодерний, доіндустріальний ландшафт, в який ii вміщено. Відтак вповні адекватна чинним викликам перед Україною, розглянута модель насправді виглядає надто архаїчно, а враховуючу найнижчу питому вагу етнонаснаженої ідентичності в іiі нинішній структурі, ще й ідеалістично. 
Нарешті, третю, модель - єдиної України - демонструє популярне фото із Ходи Гідності на честь святкування Дня незалежності 2019 року (у Телеграмі використано в каналі «Украина 24/7»). На ньому президент Зеленський у діловому костюмі позує поряд із дітьми у національними вбранні та кремезними чоловіками у військовій формі (рис. 4.). На нашу думку, тут сфокусовано суть можливих новітніх візій української ідентичності, як сучасної громадянсько-політичної ідентичності із тонкою мілітарною амальгамою й укоріненням у традиційній народній культурі. Проте, реалізація подібної програми є можливою лише внаслідок системної політики, медійний аспект якого є важливим, але не провідним.

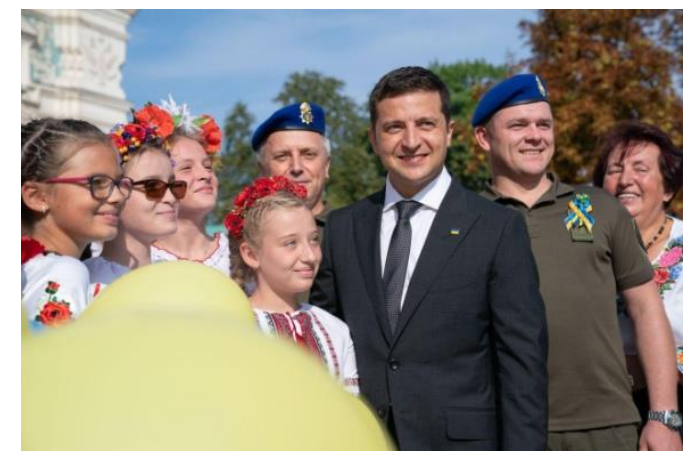

Рисунок 4 - Образ України як сучасної обороноспроможної держави

Аналіз репрезентації української ідентичності у візуальному контенті 5 топових Телеграм-каналів («Украина 24/7», «Украина сейчас», «Украина Online», «ТСН» (телеграмна служба новин), «Инсайдер UA») виявив дві групи ії маркерів Через велику сенсонавантаженість їх питому вагу слід рахувати значно вищою, ніж формальні по 23\% від загального візуального масиву. Їх було умовно позначено як Political Identity, (сполучення синьо-жовтих кольорів, прапор чи тризуб, банкнота як центр зображення або домінуючий фон) та Military (чоловіки та жінки в українській військовій формі, зброя та військова техніка). Домінуючою є перша група, яка уособлює громадянськополітичну ідентичність. Її поширення можна пояснити і загальносвітовими тенденціями, і вищим місцем в ієрархії ідентичності українців, і спрямуванням внутрішньої політики чинної влади на «громадян України», не недиференційованих за геополітичними і ціннісними уподобаннями. Продукування маркерів Military більшою мірою пояснюється збереженням актуальності військових новин в умовах неоголошеної війни між Росією та Україною. Воно відображає також стан часткової мілітарної мобілізації суспільної свідомості упродовж останніх 6 років. Від свого традиційного носія - реальної, етнонаснаженої ідентичності, трансляція подібних образів в Telegram є відірваною, адже їх ідентифікаційні характеристики (форма, шеврони, нашивки, нагороди, знаки на військовій техніці) не винесено на передній план.

У попередніх дослідженнях автора, напроти, виявилося значно важче простежити громадянсько-політичну версію національної специфіки України в соціальних мережах Фейсбук та Інстаграм. Там переважали зображення, які можна віднести до етнокультурної версії української ідентичності, зазвичай, фемінізовані i рустикалізовані образи України. Більша питома вага супровідних мілітарних образів (14\% від загального візуального масиву у фейсбук-спільнотах), наявність в їх візуальному контенті особливого «жіночого мілітарі (3\%) насправді не змінювали наратив «Україна, як жінка, війни не хоче».

У зазначених медійних каналах фактично єдиним спільним сучасним символом України, одночасно візуальним і меморіальним, виявилися поодинокі зображення 
Монументу Незалежності на однойменному майдані в Києві. На думку автора, це чітко демонструє незавершенність процесів постмодернізації України не тільки в соціальноекономічному та політичному плані, але й на рівні найважливішого, за сучасними науковими уявленнями (Р. Інглхардт) ціннісного простору, разом зі тим - культурної пам'яті та ієрархії ідентичностей. Лише за умови успішності просування на цьому шляху в поєднанні 3 проведенням системної внутрішньої політики є можливими новітніші візії української ідентичності - як сучасної громадянсько-політичної ідентичності із тонкою мілітарною амальгамою й укоріненням у традиційній народній культурі. Допоки вони репрезентуються лише постановочними фото (наприклад, фото із Ходи Гідності на честь святкування Дня незалежності 2019 року).

Серед перспективних напрямів подальшого дослідження можемо назвати, передусім, студіювання регіонального виміру української ідентичності, який представлений у ТОП-50 Телеграму каналами найбільших міст - «Х...й Днепр», «Киев оперативный», «Х...я Одесса», «Х...й Харьков». Це дослідження може стати доволі інформаційно насиченим і цікавим, оскільки перелічені мегаполіси мають аналогічні профілі в різних соціальних мережах.

\section{Список використаної літератури}

1. Геополітичні орієнтації жителів України: лютий 2020 [Електронний ресурс] / підгот. Ю. Сахно // КМIC. - Режим доступу : https://www.kiis.com.ua/?lang=ukr\&cat=reports\&id=927\&page=3 ; Heopolitychni oriientatsii zhyteliv Ukrainy: liutyi 2020 [Elektronnyi resurs] / pidhot. Yu. Sakhno // KMIS. Rezhym dostupu : https://www.kiis.com.ua/?lang=ukr\&cat=reports\&id=927\&page=3

2. Голуб О. Звідки українські беруть новини про ОСС ЗМІ [Електронний ресурс] / О. Голуб // Інститут масової інформації. - 2018. - 12 жовтня. - Режим доступу : https://imi.org.ua/articles/zvidky-ukrains-ki-zmi-berut-novyny-pro-oos-i77 ; Holub O. Zvidky ukrainski berut novyny pro OSS ZMI [Elektronnyi resurs] / O. Holub // Instytut masovoi informatsii. - 2018. - 12 zhovtnia. - Rezhym dostupu : https://imi.org.ua/articles/zvidkyukrains-ki-zmi-berut-novyny-pro-oos-i77

3. Динаміка патріотичних настроїв українців: серпень 2019 [Електронний ресурс] // Соціологічна група «Рейтинг». - 2019. - 21 серпня. - Режим доступу : http://ratinggroup.ua/research/ukraine/dinamika_patrioticheskih_nastroeniy_ukraincev_avgus t 2019.html ; Dynamika patriotychnykh nastroiv ukraintsiv: serpen 2019 [Elektronnyi resurs] // Sotsiolohichna hrupa «Reitynh». - 2019. - 21 serpnia. - Rezhym dostupu : http://ratinggroup.ua/research/ukraine/dinamika_patrioticheskih_nastroeniy_ukraincev_avgus t_2019.html.

4. Половинчак Ю. Сучасне інформаційно-комунікаційне середовище як простір трансформації української національної ідентичності : монографія / Ю. Половинчак. Київ : НБУВ, 2017. - 372 с. ; Polovynchak Yu. Suchasne informatsiino-komunikatsiine seredovyshche yak prostir transformatsii ukrainskoi natsionalnoi identychnosti : monohrafiia / Yu. Polovynchak. - Kyiv : NBUV, 2017. - 372 s.

5. Рейтинг мобільних додатків за березень 2020 [Електронний ресурс] // KANTAR. - Режим доступу : https://tns-ua.com/news/reyting-mobilnih-dodatkiv-za-

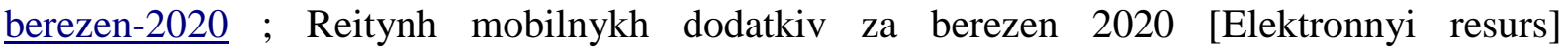
// KANTAR. - Rezhym dostupu : https://tns-ua.com/news/reyting-mobilnih-dodatkiv-zaberezen-2020

6. Рівень підтримки громадянами вступу України до СС та НАТО (січень 2020p.) [Електронний ресурс] // Центр Разумкова. Український центр економічних та політичних досліджень ім. О. Разумкова. - 2020. - 31 січня. - Режим доступу : 
http://razumkov.org.ua/napriamky/sotsiologichni-doslidzhennia/riven-pidtrymky-

gromadianamy-vstupu-ukrainy-do-yes-ta-nato-sichen-2020r ; Riven pidtrymky hromadianamy vstupu Ukrainy do YeS ta NATO (sichen 2020r.) [Elektronnyi resurs] // Tsentr Razumkova. Ukrainskyi tsentr ekonomichnykh ta politychnykh doslidzhen im. O. Razumkova. - 2020. - 31 sichnia. - Rezhym dostupu : http://razumkov.org.ua/napriamky/sotsiologichni-doslidzhennia/riven-pidtrymky-

gromadianamy-vstupu-ukrainy-do-yes-ta-nato-sichen-2020r

7. Рябчук М. Долання амбівалентності. Дихотомія української національної ідентичності - Історичні причини та політичні наслідки / М. Рябчук. - Київ : ІПіЕНД iм. І.Ф. Кураса НАН України, 2019. - 252 с. ; Riabchuk M. Dolannia ambivalentnosti. Dykhotomiia ukrainskoi natsionalnoi identychnosti - Istorychni prychyny ta politychni naslidky / M. Riabchuk. - Kyiv : IPiEND im. I.F. Kurasa NAN Ukrainy, 2019. - 252 s.

8. Ставлення українців до вирішення питання окупованих територій [Електронний ресурс] // Соціологічна група «Рейтинг». - 21 жовтня 2019. - Режим доступу : http://ratinggroup.ua/research/ukraine/otnoshenie ukraincev_k_resheniyu_voprosa _okkupirovannyh_territoriy.html ; Stavlennia ukraintsiv do vyrishennia pytannia okupovanykh terytorii [Elektronnyi resurs] // Sotsiolohichna hrupa «Reitynh». - 21 zhovtnia 2019. Rezhym dostupu

http://ratinggroup.ua/research/ukraine/otnoshenie_ukraincev_k_resheniyu_voprosa_okkupiro vannyh_territoriy.html

9. Coulmas F. Identity : A very short Introduction / F. Coulmas. - New York : Oxford University Press, 2019. - 147 p.

10. Fukuyama F. Identity: The Demand for Dignity and the Politics of Resentment / F. Fukuyama. - New York : Farrar, Straus and Giroux, 2018. - 218 p.

11. Social Media State. Apr. 2019-Apr. 2020 [Electronic resource] // StatCounter. Mode of access : https://gs.statcounter.com/social-media-stats/all/ukraine

Стаття надійшла до редакції 15.04.2020

\section{K. Kysliuk}

FEATURES OF THE REPRESENTATIONS OF UKRAINIAN IDENTITY IN THE VISUAL CONTENT OF POPULAR TELEGRAM CHANNELS

In the article had been considered the features of the representations of Ukrainian identity in the visual content of 5 most popular Telegram-channels ("Ukraine 24/7»; "Ukraine now», "Ukraine Online», "TSN», "Insider UA»). Two groups of its markers had been determineted - Political Identity (combination of blue-yellow colors, national banner or emblem (trident) as the center of the image or the dominant background) and Military (man and women in Ukrainian military uniforms, weapons and military equipment) In fact, the share of which markers had been highest than formally 2-3\% of the total visual content for every group.

The first group, which embodies the civic and political identity, had been determineted as a leading Its spread had been explained by the direction of the current government's domestic policy on «citizens of Ukraine» who were not differentiated according to geopolitical and value preferences.

The production of Military markers had been explained by the continuing relevance of military news in the context of the undeclared war between Russia and Ukraine. It also reflects the state of partial military mobilization of public consciousness over the past 6 years. The broadcast of such images in the Telegram had been detached from its traditional basisa real, ethnically charged identity. Whose identification characteristics (uniform, chevrons, stripes, awards, badges on military equipment) had been not brought to the center of image. 
On the basis of previous researches of the author had been noted that another ethnically charged level of Ukrainian identity was more widely represented on social networks Facebook and Instagram. There Ukraine was associated with a woman in a national costume or an image of a field with ripe wheat or sunflower. The greater share of accompanying military images (14\% of the total visual array in Facebook communities), the presence in their visual content of a special female military (3\%) did not really change the narrative "Ukraine as a woman does not want war».

In these communication channels had been found the only common present day symbol of Ukraine, both visual and memorial, - the images of the Independence Monument on the square of the same name in Kiev. This clearly demonstrates the incompleteness of Ukraine's postmodernization processes, including at the area of values, cultural memory and the hierarchy of identities.

Keywords: identity, culture, media, Telegram, Ukrainian identity, Ukrainian culture.

\section{УДК 316.77:[327(477):061.1НАТО]}

\section{В. О. Кудлай, С. О. Цебро}

\section{РОЗВИТОК КОМУНІКАТИВНОЇ КУЛЬТУРИ СПІВРОБІТНИЦТВА УКРАЇНА-НАТО}

Розглянуті особливості сприйняття понять «комунікативна культура» та «комунікативна настанова» в контексті дипломатичних зносин між Україною та Організацією Північноатлантичного договору. Проаналізована культура діяльності місії України при НАТО, форми взаємодіі Україна-НАТО. Окреслені визначні події, щзо сприяли розвитку комунікативної культури співробітництва сучасної України з Організацією Північноатлантичного договору.

Ключові слова: комунікативна культура, комунікація, дипломатія, співробітництво, євроатлантична інтеграція, НАТО, Украӥна.

DOI 10.34079/2226-2830-2020-10-19-48-54

Культура комунікації між такими суб'єктами як держави та міжнародні організації $\epsilon$ важливим аспектом багатогранної дипломатичної практики. До неї належать дипломатична комунікація, а також комунікативна установка, що реалізується засобами представницьких заходів дипломатичних представництв, місій при міжнародних організаціях, їх діяльність загалом. Дипломатична комунікація вимагає від учасників вмінь дотримуватись меж фаховості у побудові діалогу, досягати консенсусу без компрометації цілісності національних інтересів, виявляти повагу до взятих зобов'язань, практичних навичок кооперації у сфері зв'язків з громадськістю для боротьби з деструктивною пропагандою та поширення виважених інформаційних повідомлень, що грунтуються на фактах. Важливими комунікативними формами роботи НАТО з країнами колишнього Варшавського договору є регулярне проведення інформаційних кампаній з пояснення мети та важливості присутності НАТО у цих регіонах, організація трансляцій відеоматеріалів 3 демонстрацією реальної роботи контингенту НАТО (що унеможливлюватиме ефект від пропагандистських 